\title{
A post-humanist deconstruction of the modern continental aesthetic tradition
}

\author{
Frikkie Potgieter
}

\author{
* Frikkie Potgieter is Senior Lecturer in Art \\ History in the Department of Art History, Visual \\ Arts and Musicology at the University of South \\ Africa
}

\begin{abstract}
The modern Continental aesthetic and artistic tradition is often placed in the humanist camp and implicated in the construction of totalising subject formations. In this article I emphasize the other side of the coin by analysing deconstructive tendencies at work in this tradition. I specifically note instances of metaphorical phrasing, as well as a broader "metaphorical" understanding of art that undermines the notion of a common, humanist aesthetic experience.
\end{abstract}

'Mankind' does not advance, it does not even exist. - Nietzsche (1967b, 55).

\section{Introduction ${ }^{1}$}

The contribution made by modern Continental philosophers to post-humanism and the deconstructive thrust in the humanities in general have received ample academic attention in recent years. ${ }^{2} 34$ With reference to Continental philosophers such as Marx, Nietzsche, Heidegger and Foucault, Feenberg $(2000,152)$ rather wittily points out that 'we have a great posthumanist tradition behind us'. However, in my estimation one aspect of modern Continental philosophy, namely the aesthetic and artistic tradition, and the contribution it has made to deconstructing humanism, has been somewhat neglected. In fact, the modern Continental aesthetic and artistic tradition is often placed in the humanist camp and implicated in the construction of totalising subject formations. ${ }^{5}$

In this article I emphasise the other side of the coin by analysing deconstructive tendencies at work in the modern Continental aesthetic tradition. In this endeavour I am, of course, indebted to Derrida's deconstruction, which is well explained by Norris $(1987,19)$ as

the vigilant seeking-out of those 'aporias', blindspots or moments of self-contradiction where a text involuntarily betrays the tensions between rhetoric and logic, between what it manifestly means to say and what it is nonetheless constrained to mean. To 'deconstruct' a piece of writing is therefore to operate a kind of strategic reversal, seizing on precisely those unregarded details (casual metaphors, footnotes, incidental turns of argument) which are always, and necessarily, passed over by interpreters of more orthodox persuasion.

In line with this strategy, my central argument is that a 'vigilant' reading of important 'aesthetic texts' from the Continental tradition reveals notable instances of metaphorical phrasing, as well as a broader 'metaphorical' understanding of art, that deconstructs the possibility of proving a common humanist aesthetic. ${ }^{6}$

With regard to my focusing on metaphor, I am indebted to Derrida's deconstructive strategy of identifying metaphorical phrasing in philosophical texts. I particularly have in mind a section in Margins of philosophy (1982, 246-253) where Derrida demonstrates that Aristotle's passages in the Topics that deal with the necessity of avoiding metaphors for the sake of scientific clarity are themselves riddled with metaphors. Derrida $(1982,252)$ astutely points out that: 'all the concepts which have operated in the definition of metaphor always have an origin and an efficacy that are themselves "metaphorical".' If it is true, as I aim to support in my analysis, that humans have no access to origins that are not metaphorical themselves, one effectively deconstructs the notion of discursively proving a common, universal humanist aesthetic.

Although the body of this essay consists of deconstructive readings of 'aesthetic texts' of the Continental aesthetic tradition, I start with brief sketches of (1) humanism, (2) post-structural theories of language and (3) the significance of an 'ethics of difference'. 7 Despite it being impossible to do academic justice to these topics in the available space, I include them as they assist in contextualising, validating and advancing the central aim of this article, namely deconstructive readings of the Continental aesthetic tradition.

Humanism holds that if individuals are selfconsciously reasonable, differences will dissipate into an ideal state of agreement. Degenaar $(1986,43)$ couches this in the following words: 'Liberal humanism views the human condition 
in moral terms, applied in such a way to the individual that it can be universalised. Crucial to the morality of being human is the notion of selfrealisation...' The possibility of reconciliation between self-realisation and a common humanity is beautifully expressed in the following quote written at the end of the eighteenth century by the humanist, Schiller (1954, 31): 'Every individual man carries in disposition and determination a pure ideal man within himself, with whose unalterable unity it is the great task of his existence, through all his vicissitudes, to harmonise'. Evolving predominantly from the same philosophical tradition as Schiller, poststructural theories of language have accomplished an important shift in much 'Western' thinking, a shift that reduces claims such as those made by Schiller to mere romantic nostalgia. ${ }^{8}$

In a nutshell post-structural theories of language hold that all meaningful human experiences are subject to language, but as language itself is radically conventional, arbitrary and labile, consisting only of un-hierarchical binary opposites that are present in their absence, we have no access to a true reality or final meanings. ${ }^{9}$ Or, seen slightly differently, humans have no access to an unmediated reality, as meaning results from the mediated play of differences in a network of signs that refer to nothing beyond the network itself. This view of language and the human psyche is supported by the fact that it is impossible to say (or to point to) what an abstract term such as 'love' means, except by saying that it resembles other terms like lust, affection, fondness and caring. In this regard Miller, as quoted by Neal (1988, 152), writes of 'our linguistic predicament in not being able . . . to declare what a thing is, except by saying it is something else'. The impossibility of bypassing one's language network is further demonstrated by the difficulty that arises in translation, where finding equivalents for ideas that are clear in one language often falls short in another. In this regard Nietzsche $(1986,218)$ had already remarked: 'The different languages, set side by side, show that what matters with words is never the truth, never an adequate expression; else there would not be so many languages'.

The above insight into language has led to the unmasking and deconstruction of entrenched humanist subject formations founded, justified and promulgated on constructions of a distinctive human nature that allegedly bypasses the play of differences between surface signifiers. I refer to thinking such as this that mistakenly regards language as a 'tool' for unlocking a preexisting reality, as correspondence thinking. Understood in this manner, thinkers such as Foucault (1970, 1972), Derrida (1978 and 1982), Lyotard (1984), Said (1978) and Kristeva (1986), to name a few, have been deconstructing correspondence thinking, one of the foundations of humanism, and as an alternative they have set about working out an 'ethics of difference'. In this respect, Kristeva has set about writing women into history in their 'irreducible difference' in distinction from the manner in which they have been constructed as the 'deficient and subordinate other of man' (West 1996, 213). Said (1978) has unmasked Western rationality as a denial of the 'other'. ${ }^{10}$ Eminently Derrida $(1982,213)$, has 'compared' Western metaphysics with so-called mythical thinking, making the point that the one is not more rational than the other, but simply different:

Metaphysics - the white mythology which reassembles and reflects the culture of the West: the white man takes his own mythology, Indo-European mythology, his own logos, that is, the mythos of his idiom, for the universal form of that he must still wish to call Reason.

For his part Lyotard $(1984,66)$ emphasises the incommensurability of different language games, arguing that the 'recognition of the heteromorphous nature of language is a first step in [the] direction [of a just ethics]. This obviously implies a renunciation of terror, which assumes that [languages] are isomorphic and tries to make them so'. In the words of West (1996, 211), an ethics of difference thus unmasks humanism as a "denial of the "other" [and a] reduction of difference to a devalued otherness for the sake of the security of our own identity'.

In summary here, one can say that poststructural theories of language with their emphasis on meaning as the un-hierarchical, mediated play of differences between surface signifiers, successfully undermine correspon- 
dence thinking, one of the important cornerstones of humanism, and in so doing, repressive knowledge claims. The task set for the rest of this paper is to highlight the contribution the modern Continental aesthetic tradition has made to the current re-thinking of humanism.

The philosophers I engage with for the purpose of showing how the modern Continental aesthetic discourse contributed to the demise of humanism are Kant, Hegel, Nietzsche and Adorno, which the reader will agree constitutes a considered, but fair sampling. To refine my focus further, I want to point out the strong connection that initially existed in the Continental philosophical tradition between aesthetics and humanism. Exemplary quotes in this regard are Kant $(1952,75)$ remarking that the aesthetic experience derives from 'grounds deep-seated and shared alike by all men' and Schiller (1954, 138) writing that 'only the communication of the Beautiful unites society, because it relates to what is common to them all'. Although my emphasising the initial linkage between humanism and aesthetics may seem contradictory in terms of the task I have set myself, it in fact is not, as the logic I follow is that this lineage set about discursively testing the hypothesis of a common, humanist aesthetic experience, and through arriving at a negative conclusion, contributed to the general deconstruction of the notion of a common humanity.

Apart from the above reason for emphasising the initial linkage between humanism and aesthetics, another reason is that the aesthetic experience, being equated with refined, disinterested sensation (in differentiation from interested, 'animalistic' instincts), seems an obvious first contender for proof of a common humanity that, at least at base level, we are all the same. After all, we do not expect others to argue when we judge a flower to be beautiful, whereas we expect to be asked reasons for judging, let's say, a politician, to be corrupt.

However, theoretically proving agreement in the aesthetic experience created many philosophical dead ends, one of the most interesting being attempts at reconciling a supposed humanist aesthetic essence with creativity - a quality that was highly prized since at least the renaissance. Or, seen from a slightly different angle, how is it possible that the contingencies of artistic creativity can at the same time harbour an aesthetic essence? In this regard, think of a tune that one hears for the first time, which (as tends to happen) often has immediate appeal. To especially romantic thinkers this kind of experience such as we also find in new painted and sculpted harmonious compositions was an outward manifestation that originality (the new tune or composition) and origin (the musical scales or laws of harmony on which the new creation is based) are reconcilable. ${ }^{11}$ After such experiences, what was left to do was to prove this in theory, to be able to claim that a humanist aesthetic ontology can be reconciled with the contingencies of artistic creativity. This can be seen as an endeavour to reconcile originality and origin, which, were it successful, would thus provide theoretical proof of a progressive, creative aesthetic experience that could at the same time be 'shared alike by all men', and as such could be a significant step towards proving a common humanity. ${ }^{12}$

In the following reading of passages by Kant and Hegel, I will concentrate on instances where their struggles to reconcile aesthetic originality with origin 'self-deconstruct' into metaphoric writing and concepts. Thereafter I will analyse how two subsequent philosophers of the same Continental lineage, Nietzsche and Adorno, contribute to this metaphoric, deconstructive thrust in their deliberations on reconciling origin and originality in the aesthetic experience.

\section{Kant}

In the third critique Kant (1952, 42-51) attempts to deduce an ontological aesthetic, arguing that it must be disinterested, or, in poststructural terms, unmediated. He identifies aspects such as cognitive judgements, sensate pleasures such as eating, a rational joy in goodness, formal harmony, charm, emotion and perfection, none of which qualify as 'pure' aesthetic judgements because they are not disinterested. After excluding what seems to be almost all forms of cognition, the closest he comes to defining aesthetic judgements is to claim that they result from the 'free play' between understanding and imagination (1952, 58). However, as 'free play' is open-ended, it is obvious that he has not proven an ontological aesthetic, but rather the opposite, the impossibility of deducing such an aesthetic. 
Despite this, Kant continues with ingenious attempts at reconciling an assumed ontological aesthetic (an origin) with creativity (originality). One line of thinking he follows is that the work of art must look like a product of nature (origin), although it is not one (originality). He (1952:167) writes:

Hence the finality in the product of fine art, intentional though it be, must not have the appearance of being intentional; i.e. fine art must be clothed with the aspect of nature, though we recognize it to be art.

Cleverly Kant $(1952,168-183)$ then argues that the artistic genius should be able to create a product that looks like a product of nature, although it is not, as the talent for art was received from Mother Nature in the first place. In this manner, Kant's artistic genius supposedly reconciles objectivity and subjectivity, origin and originality. However, this argument is problematic as it is circular: the logic it follows is that the artistic genius can produce a product that looks like nature, because nature produced the artistic genius which in fact leaves no scope for the subjective originality of the artist.

Later, however, Kant (1952, 175-176) magnanimously admits to failing in reconciling origin and originality through the argument of the artistic genius by stating unequivocally that the product of the genius is a

representation of the imagination which induces much thought, yet without the possibility of any definite thought whatever i.e. concept, being adequate to it, and which language, consequently, can never get on level terms with or render completely intelligible.

Here Kant clearly has 'literal'language in mind, being notorious for the driest of prose. He also stated on more than one occasion that philosophy should not be inventive when lacking words, as it is better 'to examine the dead and learned languages, with the hope and the probability that we may there meet with some adequate expression of the notion we have in our minds' (1893, 220 and 1952, 75). However, in desperation Kant switches to metaphoric language in a last bid to reconcile aesthetic origin and originality. I have the following passage in mind $(1952,183)$ :
Taste, like judgement in general [origin], is the discipline (or corrective) of genius [originality]. It severely clips its wings, and makes it orderly and polished; but at the same time it gives it guidance, directing and controlling its flight, so that it may preserve its character of finality. It introduces a clearness and order into the plenitude of thought, and in so doing gives stability to the ideas, and qualifies them at once for permanent and universal approval, for being followed by others, and for a continually progressive culture.

Kant thus switches to a kind of metaphoric performance when his attempt at reconciling origin and originality through 'literal' analysis falls short. Far from proving the existence of a humanist aesthetic, Kant himself succumbs to the contingencies of metaphoric play, foreshadowing the post-structural insight that language does not 'discover' reality (origins), but is sometimes responsible for 'inventing' it (originality).

\section{Hegel}

In this analysis of Hegel's 'aesthetics' I argue that he shifts from understanding art history as collaborator in a world teleology, to appreciating it as metaphorically open-ended, thereby deconstructing the humanist idea of a world history of art. I start by reading Hegel in the traditional manner, namely as 'the last philosopher of the book'; thereafter I read him in a posthumanist manner, namely as 'the first thinker of writing. ${ }^{13}$

\section{The last philosopher of the book}

At the beginning of his Aesthetics, Hegel (1993) attempts to justify art as a subject for philosophical study, writing confidently that philosophy can 'ascertain scientifically what art is' (1993, 13 ) and that it can arrive at 'knowledge of the essence of fine art' $(1993,16)$. However, true to his teleological dialectic, it soon becomes clear that he does not believe that philosophy can discover the essence of art through scientific analysis, but that, instead, sensual historical artistic production is partly responsible for bringing philosophy to full self-realisation, to 'absolute knowledge'. An example of Hegel's $(1975,102)$ teleological, dialectical reasoning in this regard is the following: 
[I]n the case of the Greeks, art was the highest form in which the people represented the gods to themselves and gave themselves some awareness of truth ... And it was not as if these ideas and doctrines were already there, in advance of poetry, in an abstract mode of consciousness as general religious propositions and categories of thought, and then later were only clothed in imagery by artists and given an external adornment in poetry; on the contrary, the mode of artistic production was such that what fermented in these poets they could work out only in this form of art and poetry.

On the one hand Hegel assigns to art a creative function (originality), as truth does not pre-exist and is then mirrored by art, but on the other hand what is brought to light through art is somehow pre-determined (origin). I say this in response to his comment that 'what fermented in these poets they could work out only in this form of art and poetry'. In a nutshell, then, Hegel understands art as a sensual but essential component of a determinist dialectical process, where this sensual component eventually helps history to transform into rational, absolute knowledge.

Moreover, one must keep in mind that Hegel did not believe that he was simply describing an inevitable teleological process, but rather that he felt that his philosophy was the culmination of this process. Norris $(1984,201)$ explains as follows:

Consciousness [Hegel's consciousness] and history . . . unite at some point of maximal lucidity and hard-earned knowledge where thought comprehends, through its own selfpresent activity, the dialectic which has worked to produce that encompassing knowledge.

Thus, having had the insight to grasp the role that sensual art has performed in bringing rational, absolute knowledge to fruition, Hegel (1993, 12-13) has attained absolute knowledge himself (of course I say this tongue in cheek) and the historic task of art is complete; therefore he must divorce current and future art from a humanist world history. That is why he (1993, 12-13) writes:
The peculiar mode to which artistic production and works of art belong no longer satisfies our supreme need. We are above the level at which works of art can be venerated as divine, and actually worshipped ... In all these respects art is, and remains for us, on the side of its highest destiny, a thing of the past.

\section{The first thinker of writing}

Significantly, the above all-encompassing, 'macro', artistic teleology has strong parallels with a 'micro'process that Hegel names 'Aufhebung'. In his Aesthetics Hegel (1975, 404) explains that

every language already contains a mass of metaphors. They arise from the fact that a word which originally signifies only something sensuous is carried over into the spiritual sphere... [where] gradually the metaphorical element in the use of such a word disappears and by custom the word changes from a metaphorical expression, because, owing to readiness to grasp in the image only meaning, image and meaning are no longer distinguished and the image directly affords only the abstract meaning itself instead of a concrete picture.

One can further elucidate this claim by considering the word 'nothing'. Where the word nothing in all likelihood initially denoted 'no thing' - the absence of a physical object - we have stopped thinking like this when hearing the word, but rather think of a kind of abstract nothingness.

Clearly Hegel's 'Aufhebung' has strong parallels with his teleology, with the crucial difference that where the former is dependent on the 'greater purposes of Geist' (Taylor 1975, 74) for plausibility, the latter foregrounds language and can be understood on purely 'human' grounds; in fact the latter parallels current understanding regarding the metaphoric creation of meaning. I say this because metaphoric processes are understood as ones where clear meaning (an origin) and a new unclear 'spin' on that meaning (originality) can, as it were, 'aufhebung' into 
new clear meaning - or, explained differently, where expressions that are initially concrete, sensual or figurative transform into clear meaning (at least qualified clear meaning) through very complex historical processes.

In conclusion here, one can thus say that Hegel divorced art from determinist teleology, not to proclaim 'the death of art', but so that artists, according to Shapiro (1992, 185-186), 'would become inspired and cheerful players in an inexhaustible game of the imagination'. In doing this, Hegel in fact surreptitiously deconstructs the humanist notion of a world history of art and foreshadows the current metaphoric understanding of it.

\section{Nietzsche}

In many ways, Nietzsche's aesthetics can be read as a critique of Kant's and Hegel's. Regarding his critique of Kant's aesthetic, humanist 'thing as such', Nietzsche (1967b, 301) writes: 'But even supposing that there were an in-itself, an unconditioned thing, it would for that very reason be unknowable! Something unconditioned cannot be known; otherwise it would not be unconditioned!' Furthermore he (1967b, 168) writes:

- Art, knowledge, morality are means: instead of recognizing in them the aim of enhancing life, one has associated them with the antithesis of life, with 'God' - also as the revelation of a higher world which here and there looks down upon us through them

It is clear that Nietzsche rejects any claim to human cognition that purports to transcend human processes.

Contrary to Hegel's position (when read as the last philosopher of the book) that 'art is, and remains for us, on the side of its highest destiny, a thing of the past', Nietzsche claims: 'Only as an aesthetic phenomenon is the word and existence eternally justified'. ${ }^{14}$ Nietzsche says this as he wants to overcome a final 'aufhebung', which for him amounts to absolute nihilism. Instead of wishing for some point of arrival, we should accentuate creative metaphoric processes, saying 'Yes' to life, to the open-ended unfolding of the future. His (1967b, 298) comment on this is the following:
'Truth' is therefore not something there, that might be found or discovered - but something that must be created and that gives a name to a process, or rather to a will to overcome that has in itself no end introducing truth, as a processus in infinitum, an active determining - not a becoming-conscious of something that is in itself firm and determined. It is a word for the 'will to power'.

Furthermore, the artist is his prime superman, his prime motivator for life, because 'man must be a liar by nature, he must be above all an artist', and 'whenever man rejoices ... . he rejoices as an artist, he enjoys himself as power, he enjoys the lie as his form of power'(Nietzsche 1967b, 452).

Although Nietzsche and Hegel agree that art functions on a sensual, pre-conceptual, prediscursive dimension, and that through metaphoric 'aufhebung' this dimension can transform into literal concepts, Hegel accentuates the profits of this process, whereas Nietzsche accentuates the losses. The reader will recall Hegel's explanation of 'Aufhebung' above; compare that with Nietzsche's (1986, 219) answer to the question 'What is truth?':

A mobile army of metaphors, metonyms, and anthropomorphisms - in short, a sum of human relations, which have been enhanced, transposed, and embellished poetically and rhetorically, and which after long use seem firm, canonical, and obligatory to a people: truths are illusions about which one has forgotten that this is what they are; metaphors which are worn out and without sensuous power; coins which have lost their pictures and now matter only as metal, no longer as coins.

Hence, according to Nietzsche, all that can happen to Hegel's sensual metaphor is that it can become an illusion that one has forgotten is an illusion. (Also note Nietzsche's use of 'obligatory to a people', denoting a denunciation of a humanist, teleological 'Aufhebung'.)

In the following passage, which must surely be one of the most beautiful written by a philosopher, Nietzsche $(1955,238)$ praises the sensual processes and experiences that precede cognitive, discursive meaning: 
Alas, what are you in the end, my written and painted thoughts? Not long ago you were so brightly colored, so young and wicked, so full of thorns and secret spices that you made me sneeze and laugh - and now? You have taken of your newness; some of you, I fear, are ready to turn into truths, so immortal do you already look, so heart-breakingly decent, so boring! And was it ever otherwise? What sort of thing do we copy down, we mandarins with our Chinese brushes, we immortalizers of the things that can be written? What are we able to copy down? Only, alas, what is about to fade and lose its fragrance! Only departing and exhausted thunderstorms, alas, and belated yellow feelings! Only birds, alas, who flew till they were weary and lost their way, who can be caught in the hand - in our hand! We immortalize what has not long to live, what can no longer soar - tired and hollow things!

Compare this with a previous quote by Kant (1952, 183):

Taste, like judgement in general [origin], is the discipline (or corrective) of genius [originality]. It severely clips its wings, and makes it orderly and polished; but at the same time it gives it guidance, directing and controlling its flight, so that it may preserve its character of finality. It introduces a clearness and order into the plenitude of thought, and in so doing gives stability to the ideas, and qualifies them at once for permanent and universal approval, for being followed by others, and for a continually progressive culture.

On the one hand the parallels are uncanny, for both use metaphors of birds and flying, and both use metaphoric language to engage with philosophical concepts. On the other hand Nietzsche's passage does not demonstrate the same tension between form and content as the Kantian passage: the fact that Kant reverted to metaphor (originality) in an attempt to 'contain' metaphor and argue for the 'upper hand' of universality (origin). Nietzsche flagrantly uses metaphors to lament it when ineffable experiences and thoughts become effable, become clear, for according to him, common humanist clarity denotes boredom unto death. In summary: Nietzsche deconstructs an aesthetic humanism by celebrating the labile contingencies of creative artistic play.

\section{Adorno}

In the following analysis of Adorno's aesthetics, I argue that despite his humanist predilections, his general thrust is in the direction of an ethics of difference.

On the one hand Adorno, true to his Marxist yearnings, remains a humanist because his aesthetics encompasses a movement toward attaining an earthly utopia; on the other hand he differs markedly from traditional Marxism, in that he refuses to give concrete form to what this utopia should be like. In Edgar's (1990, 52) words, he believes that 'there is no ground-plan for a perfect society, for this society cannot be known until it is achieved'. Furthermore, Adorno's aesthetics should be understood against the aftermath of the Holocaust, and especially the rise in a critical theory that tried to comprehend how aspects of enlightenment thinking could result in the gas chambers. Against this background, Adorno believes in praxis that disrupts bourgeois consciousness.

However, Adorno rejects a purely revolutionary, activist art that tries to change society through its rational content. One reason for this, as intimated above, is that we cannot know what we should aim for before it is achieved. Another reason is that Adorno $(1997,2)$ experienced his times as 'abnormal', stating that 'in the face of the abnormality into which reality is developing, art's inescapable affirmative essence has become insufferable'.

Clearly Adorno, a spokesperson for the historical avant-garde, has something different in mind from straightforward propaganda. In the same vein as Hegel, he argues that aesthetic form (especially abstract artistic form) and ethical practices resonate with one another. He $(1997,2)$ expresses this by saying: 'through the ages by means of its form, art has turned against the status quo 'However, whereas in Hegel's teleology the interaction between these spheres eventually resolves into a re-conciliation of the opposites or differences that split human consciousness, Adorno's dialectic requires the continual disruption of the status quo. He refers to this as negative dialectics, and in art this 
amounts to a continual disruption of aesthetic harmony.

One can explain his position further by saying that in an un-emancipated society, aesthetic harmony may have the effect of sublimating suffering. Wolff $(1981,89)$ expresses this in the following manner: 'The arts may express and depict great inequalities and suffering, but because these are transposed on to the aesthetic level, they simply act in a cathartic manner and in the process affirm the existing social relations'. Similarly Adorno $(1997,15)$ states: 'the concept of aesthetic pleasure [harmonious art] as constitutive of art is to be superseded'. According to him, only inharmonious art can accomplish renewal. In appreciation of Schönberg's a-tonal music, he (1967, 149-150) writes:

Schönberg's music demands from the very beginning active and concentrated participation, the most acute attention to simultaneous multiplicity, the renunciation of the customary crutches of a listening which always knows what to expect ... It requires the listener spontaneously to compose its inner movement and demands of him not mere contemplation but praxis.

At this point one could question why the very praxis that abstract, dissonant art triggers, should necessarily lead to improved emancipation, especially as such art arises out of the present 'false' consciousness itself. I take a short cut here, by not comprehensively analysing how in this regard his wordplay - reminiscent of the Hegelian dialectic - 'self-deconstructs'. Suffice it to say that formulations such as 'The work wants its truth and untruth to be grasped' (Adorno 1997, 15), far from proving a determinist, emancipatory compulsion in dissonant works of art, in fact only prove the impossibility of proving this.

However, after removing all deterministic pretensions from Adorno's 'aesthetics', his enterprise of replacing humanist, harmonious, reconciliatory aesthetics - the reconciliation of origin and originality - with an aesthetics of perpetual dissonance and discord, foreshadows the current ethics of difference. From Adorno's negative dialectic, it is also not a long way to the current interest in the abject - the fascination with shocking 'bodiliness' - a very real part of our human, or shall I say, post-human, condition.

\section{Conclusion}

The deconstructive work accomplished in this article has drawn attention to how Kant failed to reconcile origin and originality in his argument concerning the artistic genius, to how Hegel divorced art from a world teleology, to how Nietzsche celebrated ineffability, and to how Adorno 'unproved' teleology in dissonant works of art. From this it is reasonable to conclude that the Continental aesthetic lineage contributed to the moral bankruptcy of a humanist aesthetic experience and thereby engendered the subsequent emancipatory ethics of difference.

However, even today, if someone asks, 'What is beauty?' a good answer remains, 'I cannot tell you, but I will whistle it, or show it to you'. What this suggests is that at some level we do seem to agree on aesthetic judgements; that the failure to conceptualise a humanist aesthetic does not mean that it does not exist at any level whatsoever. Or, more specifically phrased, the impossibility of discursively conceptualising a humanist aesthetic experience does not exclude the possibility that metaphoric play in a work of art, or even between a philosophical text and a work of art, cannot accomplish some form of reconciliation or harmonisation between differences, albeit conditional.

However, importantly, this level of 'performativity' was foreshadowed by the Continental humanist aesthetic tradition I am dealing with. I say this as these writers tended toward metaphoric language when writing about experiences that, so to speak, function at the limits of language. I have pointed out how Kant switched to metaphoric language when literal language failed him. I have also noted the parallels between Hegel's 'Aufhebung' and the metaphoric creation of meaning, and that Hegel implied that his thinking was somehow part of this process. In Nietzsche's case the point is obvious, writing metaphorically as he does. ${ }^{15}$ Surely, an obscure formulation such as Adorno (1984, 31) saying that '[m]odern art is constantly practicing the impossible trick of trying to identify the non-identical' should be read as a metaphor employed to try and make an ineffable process, such as the aesthetic experience, effable? If this is the case, this 
tradition not only contributed to the rise of an ethics of difference, but also to a metaphoric perspective on art and the creation of meaning.

Personally, I see no reason why the work of art cannot create, at least at the level of sensation, feelings of togetherness. This is important, lest we become so wrapped up in our differences that we lose the capacity to see the pain on the 'other's' face. In making this last move, we also shift from an ethics of difference to a metaphoric ethical imagination, to a willingness to allow present differences and similarities, but, importantly, also future differences and similarities, to become part of the game. We should not regard differences as absolute, for as Nietzsche (1967b, 547) astutely pointed out: 'The old habit . . . of associating a goal with every event and a guiding, creative God with the world, is so powerful that it requires an effort for a thinker not to fall into thinking of the very aimlessness of the world as intended'. We might take Nietzsche seriously, and not regard differences as intended or absolute.

\section{Notes}

1 Aspects of this article were researched in my doctoral thesis. See Potgieter (1999). A shorter version of this article, entitled 'Revising Modernism from a Post-Humanist Perspective', was read at the 21st Annual Conference of South-African Visual Arts Historians, Grahamstown, South Africa, 8-11 September 2005.

2 Modern Continental philosophy refers to a German lineage that includes Kant, Hegel, Marx, Nietzsche, Freud, Benjamin, Adorno, Heidegger, Gadamer and Habermas. This lineage is continued by French philosophers such as Sartre and Merleau-Ponty, through to postmodern philosophers such as Foucault, Lyotard, Lacan, Baudrillard and Derrida. For an excellent introduction to Continental philosophy see West (1996).

3 The term post-humanism often refers to the effects of machines and technology, 'cyborgs' and artificial intelligence, on humans [In this regard see the influential work by Hayles (1999), How we became posthuman: Virtual bodies in cybernetics, literature, and informatics]. For the purposes of this article, however, I use this term to refer to an intellectual re-thinking, especially by post-structuralists, of the notion of a common humanity. [See Badmington (2000, 1-10)]. Concordantly, I use the term humanism to refer to 'the notion of a core humanity or common essential feature in terms of which human beings can be defined and understood' (Soper 1997).
4 For an informative compilation that traces the 'tradition' of deconstruction see Taylor (1986).

5 I specifically have in mind neo-Marxists such as Hauser (1962), Fischer (1963), Berger (1972), Jameson (1981) and Duncan (1993), and feminists such as Pollock (1988) and Perry (1999).

6 I use the phrase 'metaphorical understanding of art', and later in this essay I speak of 'the current metaphoric understanding of art', to refer to a theoretical position that rejects ontological and teleological claims with regard to art replacing it with a view that understands art as the play with surface signifiers.

7 In this regard West $(1996,213)$ uses the following heading: Politics of difference and ethics of the other.

8 Although, as pointed out by an astute reader, one should acknowledge Schiller's concept of the split self as it is itself explored in post-structural discourse.

9 See Rorty (1967), Culler (1983), Norris (1982) and Potgieter (1999, 145-153) for further elucidation of post-structural theories of language.

10 See West $(1996,215)$.

11 Elsewhere I have unpacked in some detail how reconciling creative open-endedness with an aesthetic essence, became a standard problem with 'romantic' thinkers such as Schiller, Schelling, Coleridge and Schopenhauer. See Potgieter (1999, 48-52).

12 In further support of this analysis, I would like to remind the reader of Degenaar's $(1986,43)$ 'definition'of humanism, namely that humanism 'views the human condition in moral terms, applied in such a way to the individual that it can be universalised, as it parallels the attempts that were made to harmonise aesthetic individuality (originality) and universality (origins)'.

13 For this wording and idea I am indebted to Taylor $(1986,4)$, although he does not apply it directly to art as I do.

14 Nietzsche makes this claim in a number of places in The birth of tragedy and the case of Wagner (1967a).

15 Heidegger, whom I did not discuss, theorised about how language makes us what we are, and practised what he theorised in philosophical texts, writing sentences such as the following in an attempt to reconcile origin and originality: 'The dawning world brings out what is as yet undecided and measureless, and thus discloses the hidden necessity of measure and decisiveness' (Heidegger 1986, 272). 


\section{References}

Adorno, T. W. 1967. Prisms. London: Neville Spearman.

- 1984. Aesthetic theory. London: Routledge. - 1997. Aesthetic theory, eds. G. Adorno and R. Tiedemann. Newly trans., ed., and with a translator's introduction by R. Hullot-Kentor. London: Athlone.

Badmington, N, ed. 2000. Posthumanism. Basingstoke: Palgrave

_. 2003. Theorizing posthumanism. Cultural Critique 53, Winter: 10-27.

Berger, J. 1972. Ways of seeing. Harmondsworth: Penguin.

Cooper, D. E. ed. 1992. A companion to aesthetics. Oxford: Blackwell.

Culler, J. 1983. On deconstruction: Theory and criticism after structuralism. London: Routledge \& Kegan Paul.

Degenaar, J. J. 1986. Art as involvement in the human condition: social criticism, in Art and the meaning of life, paper published by the Department of Adult Education and Extra-Mural Studies of the University of Cape Town: 39-46.

Derrida, J. 1978 [1967]. Writing and difference. Trans. A. Bass. Chicago: Chicago University Press.

_. 1982. Margins of philosophy. Trans. A. Bass. Chicago: Chicago University Press.

Duncan, C. 1993. The aesthetics of power: Essays in critical art history. Cambridge: Cambridge University Press.

Eagleton, T. 1990. The ideology of the aesthetic. Oxford: Basil Blackwell.

Edgar, A. 1990. An introduction to Adorno's aesthetics. British Journal of

Feenberg, A. 2000. Will the real post-human please stand up!: A response to Elichirigoity. Social Studies of Science 30(1), February:151-157.

Fischer, E. 1963. The necessity of art: A Marxist approach. Trans. A. Bostock. Harmondsworth: Penguin.

Foucault, M. 1970. The order of things: An archaeology of the human sciences. Trans. from the French. London: Tavistock.

- 1972. The archaeology of knowledge. Trans. from the French. London: Tavistock.

Hayles, N. K. 1999. How we became posthuman: Virtual bodies in cybernetics, literature, and information. Chicago: University of Chicago Press.

Hegel, G. W. F. 1975 [1842]. Hege/'s aesthetics: Lectures on fine art. Trans. T. M. Knox. 2 vols. Oxford: Clarendon.

- 1993. Hegel: Introductory lectures on aesthetics. Trans. B. Bosanquet. Ed. with an introduction and commentary by M. Inwood. Harmondsworth: Penguin.
Heidegger, M. 1986. The origin of the work of art. In Deconstruction in context: Literature and philosophy, ed. M. C. Taylor, 256-279. Chicago: University of Chicago Press. - 1993. Basic writings. Ed. and introduced by D. F. Krell. Revised and expanded ed. London: Routledge.

Hauser, N. The social history of art. Trans. S. Godman. London: Routledge \& Kegan Paul.

Jameson, F. The political unconscious: Narrative as a socially symbolic act. London: Methuen.

Kant, I. 1893 [1781]. Critique of pure reason. Trans. J. M. D. Meiklejohn. London: George Bell.

_ 1952 [1790]. The critique of judgement. Trans. J. C. Meredith. Oxford: Clarendon.

Kristeva, J. 1986. The Kristeva reader. Oxford: Blackwell.

Lyotard, J-F. 1984. The postmodern condition: A report on knowledge. Trans. G. Bennington and B. Massumi. Forwarded by F. Jameson. Minneapolis: University of Minnesota Press.

_. 1991. Rewriting modernity, in The inhuman: Reflections on time. Trans. G. Bennington and R. Bowlby. Cambridge: Polity.

Neal, J. 1988. Plato, Derrida, and writing. Carbondale: Southern Illinois.

Nietzsche, F. W. 1955 [1886]. Beyond good and evil. Trans. with an introduction by M. Cowan. Chicago: Henry Regnery.

- 1967a. The birth of tragedy and the case of Wagner. Trans. W. Kaufmann. New York: Random House.

_. 1967b [1901]. The will to power. Trans. W. Kaufmann and R. J. Hollingdale. Ed. with commentary by W. Kaufmann. London: Weidenfeld and Nicholson.

_ 1986. On truth and lie in an extra-moral sense. In deconstruction in context: Literature and philosophy, ed. M. C. Taylor, 216-219. Chicago: University of Chicago Press.

Norris, C. 1982. Deconstruction: theory and practice. London: Methuen.

_ 1984. On Marxist deconstruction: Problems and prospects. Southern Review 17(2), July: 201-211.

_ 1987. Derrida. London: Fontana/Collins.

Perry, G. 1999. Gender and art. New haven: Yale University Press.

Pollock, G. 1988. Vision and difference: Femininity, feminism and the histories of art. London: Routledge.

Popper, K. R. 1966. The open society and its enemies. 5th ed. 2 vols. London: Routledge.

Potgieter, F. J. 1999. Die ontstaan van die metaforiese perspektief op kunswaarheid en betekenis: 'n Herwaardering van die moderne artistieke prak- 
tyk. D.Phil. proefskrif. Stellenbosch: Universiteit van Stellenbosch.

Rorty, R. ed. 1967. The linguistic turn: Recent essays in philosophical method. Chicago: University of Chicago Press.

Said, E. 1978. Orientalism. London: Routledge.

Schiller. F. 1954 [1795]. On the aesthetic education of man: In a series of letters. Trans. and introduced by R. Snell. New York: Frederick Ungar. Shapiro, G. 1992. Hegel, Georg Wilhelm Friedrich. In A companion to aesthetics, ed. D. E. Cooper, 182-188. Oxford: Blackwell.
Soper, K. 1986. Humanism and ant-humanism. London: Hutchinson.

Taylor, C. 1975. Hegel. Cambridge: Cambridge University Press.

Taylor, M. C. 1986. Deconstruction in context: Literature and philosophy. Chicago: University of Chicago Press.

West, D. 1996. An Introduction to continental philosophy. Cambridge: Polity.

Wolff, J. 1981. The social production of art. London: MacMillan. 